\title{
Effect of parathyroid hormone-related protein (PTHrP) on the contractility of the myometrium and localization of PTHrP in the uterus of pregnant rats
}

\author{
E. D. Williams ${ }^{1}$, D. D. Leaver ${ }^{1}$, J. A. Danks ${ }^{2}$, J. M. Moseley ${ }^{2}$ and \\ T. J. Martin ${ }^{2}$ \\ ${ }^{1}$ Department of Pharmacology, University of Melbourne, Parkville, Victoria 3052, Australia; and \\ ${ }^{2}$ Department of Medicine, St Vincent's Institute of Medical Research, Fitzroy, Victoria 3065, Australia
}

\begin{abstract}
The effect of parathyroid hormone-related protein (PTHrP) on the contractility of uterine segments taken from pregnant rats and the localization of PTHrP in the uterus during pregnancy were investigated. $\mathrm{PTHrP}(1-34)$ had a potent inhibitory effect on spontaneous contractions of the longitudinal layer of uterine myometrium taken from rats at day 4 of pregnancy $\left(\mathrm{IC}_{50} 1.6 \mathrm{nmol} \mathrm{l}^{-1}\right)$. In low calcium De Jalon's solution, it also decreased baseline tension $\left(\mathrm{IC}_{50} 1.5 \mathrm{nmol} \mathrm{1^{-1 }}\right)$ in a concentration-dependent manner. The effect of PTHrP(1-34) on uterine motility decreased as pregnancy progressed until day 13, after which PTHrP(1-34) had no measurable effect on uterine contractility. In contrast, PTHrP(1-34) had no effect on the contractions of the circular smooth muscle of the uterus at any stage of pregnancy. PTHrP(50-69) had no effect on the contractility of either muscle layer of the myometrium. A temporal pattern of staining for PTHrP in the uterus of pregnant rats was observed, and the changes in the staining patterns in the endometrium and myometrium were different in each layer. These data suggest that PTHrP may have at least two distinct roles in the uterus, a relaxing action on longitudinal muscle that depends on the hormonal state of the rat and a novel effect either intraluminally or within the endometrial layer.
\end{abstract}

\section{Introduction}

Parathyroid hormone-related protein (PTHrP) and its messenger RNA have been identified in tissues involved with reproduction, including the developing and lactating mammary gland (Thiede and Rodan, 1988; Rakopoulos et al., 1992), placenta (Hellman et al., 1992), and pregnant myometrium (Thiede et al., 1990). Although the physiological role of PTHrP in these tissues has yet to be established, the production of PTHrP by placenta and fetal parathyroid have been implicated in the temporal transfer of calcium from mother to embryo in utero (Abbas et al., 1989). In the uterus, functions such as the control of myometrial contractility to allow successful pregnancy and parturition have also been suggested (Thiede et al., 1990).

We have demonstrated that $\operatorname{PTHrP}(1-34)$ inhibits spontaneous and electrically evoked contractions of the uterus of the cyclic rat in vitro (Paspaliaris et al., 1992). This response was shown to depend on the stage of the cycle, and was greatest at the time of oestrogen dominance. Similarly, the responsiveness of the immature rat uterus to $\mathrm{PTHrP}(1-34)$ was enhanced by oestrogen treatment and the response was reduced by additional progesterone treatment (Paspaliaris et al., 1992).

Revised manuscript received 8 April 1994
Because of the requirement for control of uterine motility during pregnancy, the effect of $\mathrm{PTHr}(1-34)$ on the contractility of both the longitudinal and circular smooth muscle layers of the pregnant rat uterus was examined.

PTHrP protein and mRNA have been demonstrated in the myometrium (Paspaliaris et al., 1992; Thiede et al., 1991), and we have also shown that PTHrP and its mRNA are present in the endometrium of the immature rat uterus (Paspaliaris et al., 1992). As the production of PTHrP in the endometrium of the uterus of pregnant rats could have an important role in implantation or the maintenance of pregnancy, the localization of PTHrP and its temporal pattern of production in the uterus of pregnant rats were examined immunohistochemically.

\section{Materials and Methods}

\section{Materials}

PTHrP(1-34) and PTHrP(50-69) were synthesized by B. E. Kemp as described previously (Kemp et al., 1987), and characterization of sheep antiserum against PTHrP(50-69) was reported by Danks et al. (1990). Porcine relaxin was provided by B. E. Kemp. 
Animals

Sprague-Dawley rats were pair-mated, and the day after the appearance of the seminal plug was identified as day 1 of pregnancy. The average duration of pregnancy for rats in this colony is 21 days. Rats were killed by decapitation between day 4 and day 21 of pregnancy.

\section{Pharmacological studies}

Segments of uterus were oriented to measure changes in contraction of longitudinal or circular muscle layers, and mounted in $14 \mathrm{ml}$ organ baths in physiological salt solution and bubbled with $95 \% \mathrm{O}_{2}$ and $5 \% \mathrm{CO}_{2}$ at $37^{\circ} \mathrm{C}$. KrebsHenseleit solution (Krebs) was used for the first part of the experiment, followed by De Jalon's solution, $\mathrm{pH}$ 7.2. The Krebs solution had the following composition (mmol $1^{-1}$ ): $\mathrm{NaCl}$, 118.0; $\mathrm{KCl}$, 4.7; $\mathrm{NaHCO}_{3}, 25.0 ; \mathrm{MgSO}_{4} \cdot 7 \mathrm{H}_{2} \mathrm{O}, 0.45 ; \mathrm{KH}_{2} \mathrm{PO}_{4}$, 1.03; $\mathrm{CaCl}_{2}, 2.5$; glucose, 11.1. The De Jalon's solution had the following composition $\left(\mathrm{mmol} \mathrm{l} \mathrm{l}^{-1}\right)$ : $\mathrm{NaCl}, 153.9 ; \mathrm{KCl}, 5.6$; $\mathrm{NaHCO}_{3}, 6.0 ; \mathrm{CaCl}_{2}, 0.25$; glucose, 2.8. Isometric tension was measured using a tension-displacement transducer and recorded on either a Rikadenki recorder or on MacLab computer software (Analog Digital Instruments, Sydney, NSW). A resting tension of approximately $2 \mathrm{~g}$ was applied to each hom, and each horn was allowed to equilibrate for at least $30 \mathrm{~min}$ before addition of $\mathrm{PTHrP}(1-34)$ or $\mathrm{PTHrP}(50-69)$ to the organ bath. The effects of PTHrP(1-34) and PTHrP(50-69) on spontaneous contractions and uterine resting tension (baseline) were then examined and cumulative concentration-effect curves to PTHrP(1-34) and PTHrP(50-69) (0.1-100 nmol 1- $\left.{ }^{-1}\right)$ were constructed. During early pregnancy, contractions were evoked in the circular smooth muscle preparations by electrical field stimulation, delivered from platinum electrodes. Trains of pulses $(2 \mathrm{~ms}, 20 \mathrm{~Hz}, 60 \mathrm{~V})$ were applied for $5 \mathrm{~s}$ every $100 \mathrm{~s}$ using a GRASS S88 stimulator. Porcine relaxin $\left(100 \mathrm{nmol} \mathrm{l}^{-1}\right)$ was used to inhibit uterine contractions in the longitudinal and circular muscle preparations as a positive control.

\section{PTHrP immunohistochemistry}

Tissue collection and preparation. Fragments $(3-5 \mathrm{~mm})$ of uteri from pregnant rats were fixed in 10\% neutral buffered formalin and embedded in paraffin blocks. Immunohistochemistry was performed on serial sections, $5 \mu \mathrm{m}$ thick, that were cut on a Leitz 1515 rotary microtome. The sections were adhered to glass microscope slides that had been treated with tissue adhesive ( $2 \% 3$-aminopropyltriethoxysilane), and dried in a $37^{\circ} \mathrm{C}$ oven overnight.

Immunohistochemistry. Peroxidase-antiperoxidase staining for PTHrP was performed as described by Danks ef al. (1989). The antiserum used was a polyclonal anti-PTHrP(50-69) antiserum (s8094) raised in sheep to synthetic PTHrP(50-69), and has previously been characterized by Danks et al. (1989). This antiserum has previously been used to detect immunoreactive PTHrP in ovine parathyroid gland (Maclsaac et al., 1991) and immature rat uterus (Paspaliaris et al., 1992). Positive and negative controls were included in each experiment. Sections of normal human skin, in which the spinous keratinocyte layer contains the PTHrP antigen (Danks et al., 1989), were used as positive controls. Negative method controls and tests for antigen specificity involved the substitution of non-immune sheep serum or pre-immune sheep serum for the primary antiserum, as well as an unrelated immune sheep serum. Preabsorption overnight of the anti-PTHrP(50-69) antiserum with excess PTHrP(50-69) was also performed.

The staining of uterine sections from three to five rats from each time point between day 4 and day 21 of pregnancy was examined. Intensity of staining was evaluated by analysing the effect of increasing dilutions of the primary antibody, and assessed by three independent observers. Staining was graded and scored (Southby et al., 1990) as negative (no positive staining, 0), weak positive staining (1), moderately strong positive staining (2) or strong positive staining (3).

\section{Statistical analysis}

Inhibition of spontaneous contractions and decrease in baseline values were expressed as a percentage of uterine response in the absence of $\mathrm{PTHrP}(1-34)$. Concentrationresponse curves for $\mathrm{PTHrP}(\mathrm{I}-34)$ were then constructed. Results are expressed as the means \pm SEM of replicate determinations ( $n=3-5$ for each day of pregnancy between day 4 and day 21, inclusive). Standard errors (SEM) and the molar concentrations producing $50 \%$ of the maximal response $\left(\mathrm{IC}_{50}\right.$ values) were calculated using REAP regression analysis (Gamma Research Systems, Melbourne, Vic.). $P<0.05$ was taken as an index of statistical significance. Data are representative of at least three experiments.

\section{Results}

\section{Effect of PTHrP(1-34) and PTHrP(50-69) on spontaneous contractions of pregnant rat uterus in vitro}

PTHrP(1-34) $\left(0.1-100 \mathrm{nmol} \mathrm{l}^{-1}\right)$ inhibited the size of the spontaneous contractions (Fig. Ia, b and Fig. 2a) of the longitudinal muscle layer of rat uterus at early stages of pregnancy in a concentration-dependent manner when the tissue was suspended in either Krebs or De Jalon's solution. The effect of PTHrP on the size of contraction was not significantly different when determined from the responses of tissues in Krebs or De Jalon's solution (data not shown). PTHrP(1-34) $\quad\left(0.1-100 \mathrm{nmol} \mathrm{I}^{-1}\right)$ inhibited baseline tension (Fig. 1b, Fig. 2b) of longitudinal muscle layer of the rat uterus at early stages of pregnancy in a concentration-dependent manner when the tissue was suspended in De Jalon's solution. The effect of PTHrP on the size of contraction and baseline tension decreased as the stage of pregnancy progressed (Fig. 2a, b). The $\mathrm{IC}_{50}$ values for $\mathrm{PTHrP}(1-34)$ on spontaneous contractions were $1.6,10$ and $20 \mathrm{nmol} 1^{-1}$ at 4,8 and 13 days of pregnancy, respectively. After day 13 of pregnancy no statistically significant effect was obtained.

Although spontaneous circular muscle activity changes from irregular contractions to strong regular contractions at term (Bengtsson et al., 1984), PTHrP(1-34) had no measurable effect on the size or baseline tension of either electrically evoked or 


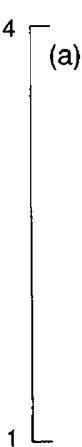

(a)

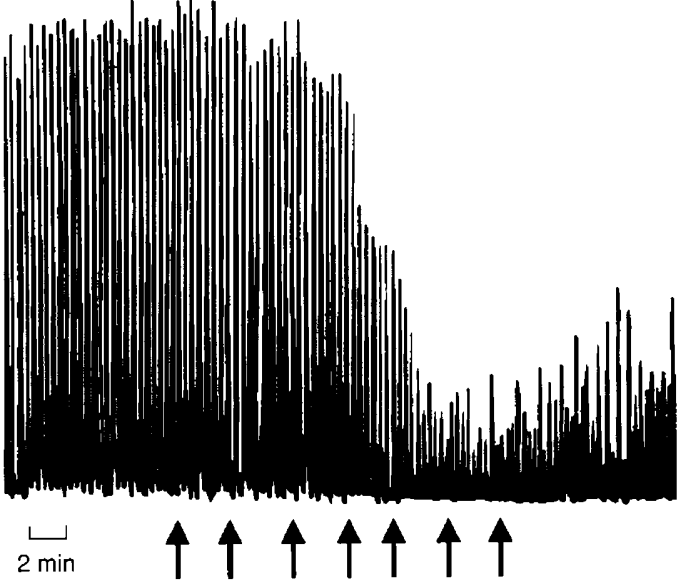

$\begin{array}{lllllll}0.1 & 0.3 & 1 & 3 & 10 & 30 & 100\end{array}$

[PTHrP(1-34)] (nmol I')

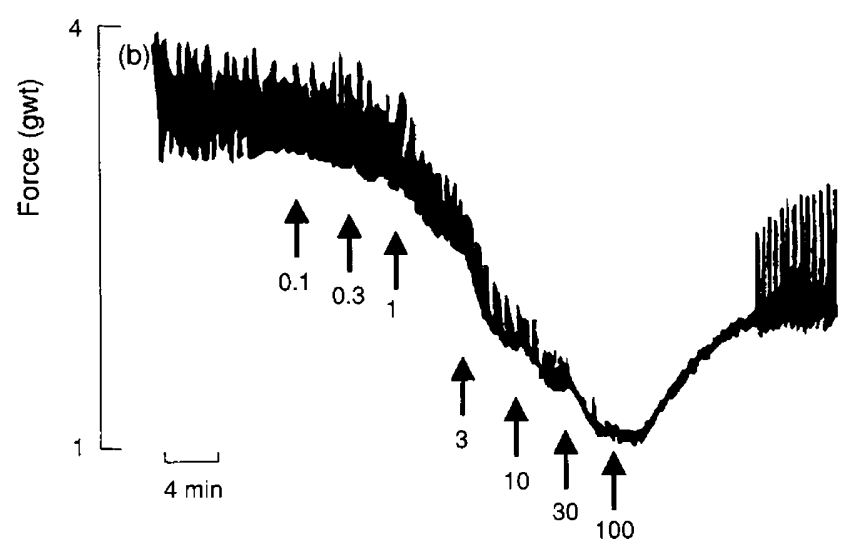

[PTHrP(1-34)] (nmol I-1)

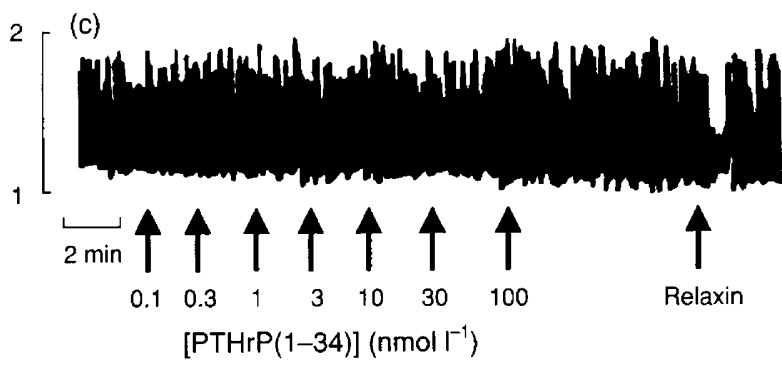

Fig. 1. (a) Recording of longitudinal contractions of a segment of uterus, from a rat at day 4 of pregnancy, suspended in Krebs' solution, showing the effect of the addition of cumulative concentrations of $\mathrm{PTHr}(1-34)$ on the size of contraction. (b) Recording of Jongitudinal contractions of the same segment of uterus as in (a) suspended in De Jalon's solution, showing the effect of the addition of cumulative concentrations of $\mathrm{PTHrP}(1-34)$ on both the size of contraction and baseline tension. (c) Recording of spontaneous circular contractions of a segment of uterus from a rat at day 17 of pregnancy, showing that PTHrP(1-34) had no effect on uterine contractility in the concentration range examined, but relaxin (100 nmol $\mathrm{l}^{-1}$ ) transiently inhibited the amplitude of contraction.

spontaneous contractions of the circular muscle layer of the myometrium at any stage of pregnancy examined (data not shown).
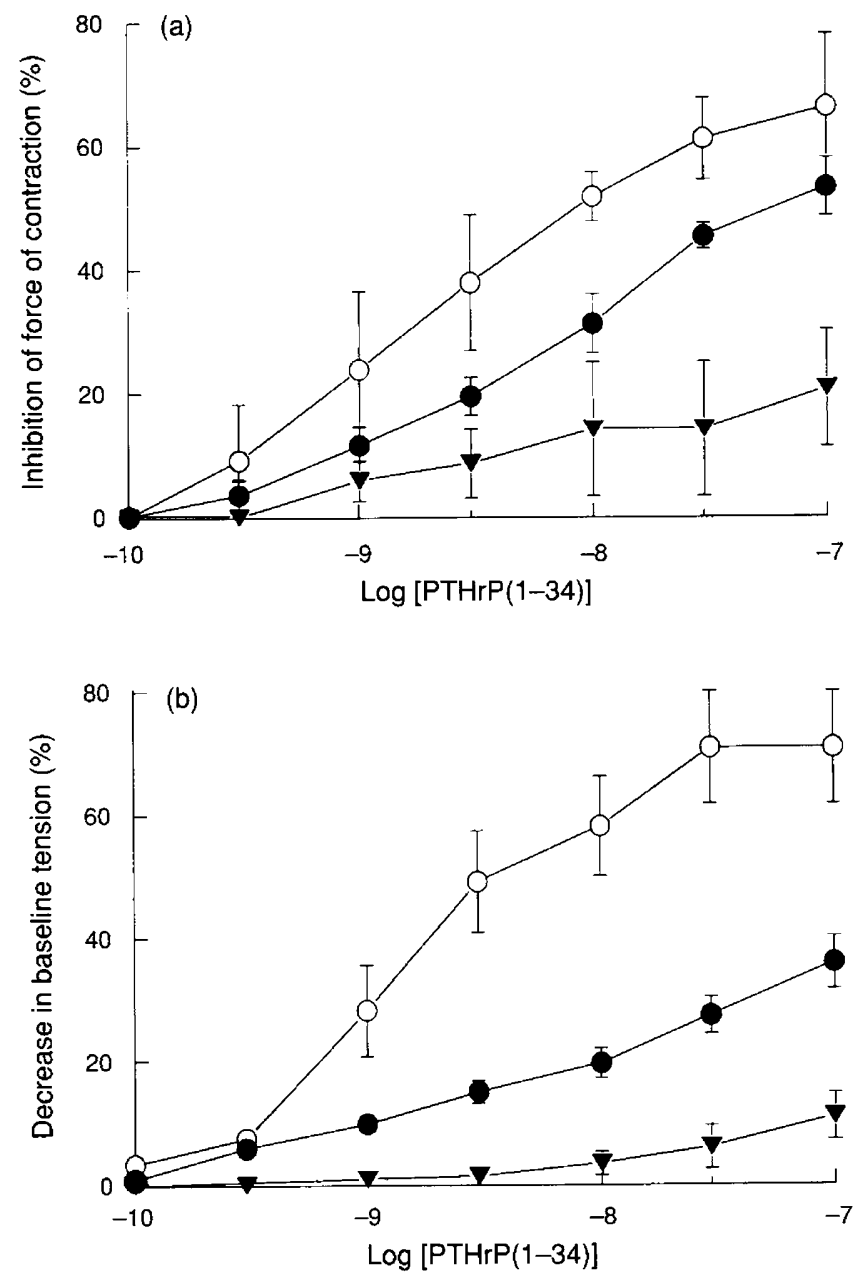

Fig. 2. (a) Inhibition of the size of spontaneous uterine contractions in rats in response to cumulative addition of $\mathrm{PTHrP}(1-34)$ at three stages of pregnancy: day $4(0)$, day $8(\mathbf{O})$ and day $13(\boldsymbol{\nabla})$. Values are means $\pm \operatorname{SEM}(n=3-5)$. (b) Decrease in baseline tension of spontaneous uterine contractions of rats in response to cumulative addition of PTHrP(1-34) at three stages of pregnancy: day $4(0)$, day $8(O)$ and day $13(\mathbf{\nabla})$. Values are means $\pm \operatorname{SEM}(n=3-5)$.

As has been reported for PTHrP(75-86) (Barri et al., 1992), $\mathrm{PTHrP}(50-69)$ had no effect on uterine contractility in either longitudinal or circular muscle preparations (data not shown).

\section{Localization of PTHrP in the uterus of pregnant rats}

PTHrP was localized immunohistochemically in the uterus of pregnant rats, and the pattern of staining changed during pregnancy. Uteri from rats at day 4 of pregnancy (Fig. 3a) showed strong positive staining (3) in the cuboidal epithelial cells lining the uterine lumen and the endometrial glands, the longitudinal layer of the myometrium, and the flattened epithelial cells of the outer serosa (5 of 5 rats). Strong specific staining (3) was observed in the circular muscle layer of the myometrium in samples from 2 of 5 rats. This staining was shown to be specific for PTHrP(50-69), as the non-immune serum control (Fig. 3b) showed no staining in any of these tissue layers. At day 6 of pregnancy, PTHrP immunostaining 

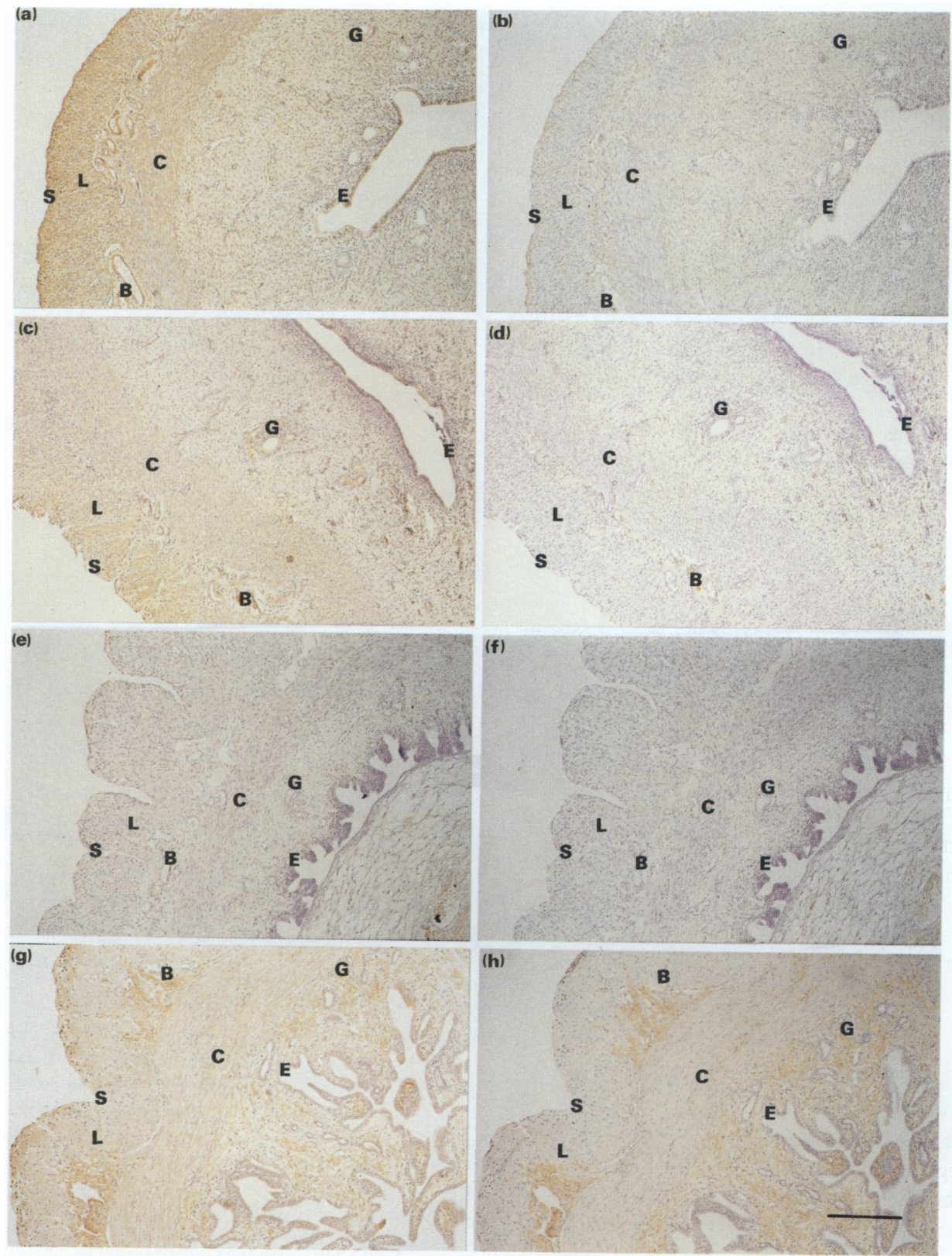

Fig. 3. Histological sections of rat uteri at different stages of pregnancy. This series of photographs are taken from the one experiment, using the same $\mathrm{hPTHrP}(50-69)$ antiserum dilution of 1:300. [hPTHrP(50-69) immunoperoxidase $\times 100]$. (a) Uterus from day 4 of pregnancy showing positive staining for hPTHrP(50-69) in the epithelial cells lining the endometrium (E) and endometrial glands $(\mathrm{G})$, longitudinal (L) and circular (C) layers of the myometrium, serosa (S) and blood vessels (B). (b) Adjacent section to (a) in which non-immune sheep serum has been substituted for the primary antibody. (c) Uterus from day 8 of pregnancy showing positive staining for hPTHrP(50-69) in the epithelial cells of the endometrium and endometrial glands, as well as the two muscle layers of the myometrium. Staining is less intense than that seen in uterine sections from rats at day 4 of pregnancy. (d) Non-immune control of (c). (e) Uterus from day 13 of pregnancy showing an absence of staining with hPTHrP(50-69) antiserum. Embryonic tissue in right corner. ( $\mathrm{f}$ ) Non-immune control of (e). (g) Uterus from day 18 of pregnancy showing positive staining for hPTHrP(50-69) in the epithelial cells of the endometrium and the myometrium. (h) Control for (g), where non-immune sheep serum was substituted for the primary anti-serum. There is increased background staining, probably due to increased enzyme activity associated with parturition. Scale bar represents $100 \mu \mathrm{m}$. 
showed the same pattern, with only slightly less intensity (3) than observed at day 4 (not shown).

On day 8 of pregnancy, PTHrP staining was markedly reduced in all layers of the uterus (Fig. 3c), but moderate positive staining (2) was still present in the epithelial cells lining the endometrial glands and both muscle layers of the myometrium ( 5 of 5 rats). At day 13 of pregnancy (Fig. 3e), no specific staining (0) was observed ( 5 of 5 rats). Some artefactual staining is seen in the outer serosa, where the tissue can become folded, and also in the blood cells in the blastocyst. This loss of staining was seen in all experiments. No specific staining was observed with increased antibody concentrations. From day 15, there was an increase in the intensity of PTHrP staining, and the staining intensity of uteri from rats at day 18-21 of pregnancy was moderate to strong (2) in the same areas as observed in uteri on day 4 of pregnancy. In the section of uterus from a rat at day 18 of pregnancy (Fig. $3 \mathrm{~g}$ ), epithelial cells lining the lumen and glands of the endometrium showed moderate positive staining (2) for $\operatorname{PTHrP}(50-69)$, as did the myometrium (both circular and longitudinal muscle layers) and outer serosa. Nonspecific staining (Fig. 3h) was seen in stromal tissue immediately below the epithelial cells and the connective tissue surrounding the blood vessels in the myometrium.

The staining intensity of the smooth muscle surrounding the blood vessels supplying the myometrium and the mesometrium varied in parallel to that of the smooth muscle of the myometrium at all stages of pregnancy examined (Fig. 3a, c).

In the initial study, substitution of non-immune sheep serum for pre-immune serum did not affect the intensity of nonspecific staining, and was therefore used in subsequent experiments. Preabsorption of the anti-PTHrP(50-69) antiserum with excess PTHrP(50-69) markedly reduced the intensity of staining in the uterine sections.

\section{Discussion}

A striking finding was the temporal nature of the response of the myometrium of the uterus of pregnant rats to $\mathrm{PTHrP}(1-34)$. At day 4 of pregnancy $\mathrm{PTHrP}(1-34)$ was most active in reducing the magnitude of spontaneous contractions and in decreasing the baseline tension of the longitudinal muscle. These responses gradually declined, and $\mathrm{PTHrP}(1-34)$ had no effect on myometrial contractility in the last third of pregnancy. In the uterus of immature rats, the relaxing action of PTHrP(134) on uterine myometrium depends on the endocrine status of the rat; it is enhanced by treatment with oestradiol and reduced by subsequent progesterone treatment (Paspaliaris et al., 1992). Hence, the peak responsiveness of the myometrium of rats at day 4 of pregnancy may be due to the peak in ovarian oestrogen concentration (Shaik, 1971) that occurs at this time, whereas the decline in responsiveness may be associated with the increasing dominance of progesterone as pregnancy progresses (Hashimoto et al., 1968). However, as there is also a high peak in oestrogen concentration before parturition without a return of myometrial responsiveness to $\mathrm{PTHrP}(1-34)$, perhaps the oestrogen:progesterone ratio or another hormone is important in controlling the responsiveness of tissue to PTHrP. Such control could be mediated by modifying either the number of receptors or the coupling between the receptor and the second messenger system in the uterine smooth muscle.

If $\mathrm{PTHrP}$ is to influence myometrial activity under physiological conditions it must act in an autocrine or paracrine fashion. Smooth muscle cells are not generally considered to be secretory cells, but evidence in support of secretion has been obtained in experiments in vitro. In these experiments, conditioned media obtained from myometrial explants and human myometrial smooth muscle cells were found to contain prolactin (Walters et al., 1983) and immunoreactive and bioactive PTHrP (Casey et al., 1992), respectively.

A feature of the response of the myometrium to $\mathrm{PTHrP}$ was that it was confined to the longitudinal layer, even though $\mathrm{PTHrP}$ was usually localized in both layers. A similar differential response was also demonstrated for relaxin, which has different actions on the two layers of the uterus (Chamley and Parkington, 1984).

PTHrP was also shown to be present in the smooth muscle of blood vessels within the uterus of pregnant rats. Since $\mathrm{PTHrP}$ exhibits vasodilatory properties in many vascular beds (Winquist et al., 1987; Trizna and Edwards, 1991) it could contribute to changes in blood flow to the uterus that occur during pregnancy. Such an effect would require independent regulation of the response of the smooth muscle in the myometrium and blood vessels to $\mathrm{PTHrP}$, perhaps by differential regulation of receptors, as the myometrium was refractory to the effect of PTHrP in the second half of pregnancy, when the substantial increase in blood flow to the uterus of pregnant rats takes place.

Immunostaining of the endometrium showed a temporal pattern for the production of $\mathrm{PTHrP}$, and staining was most intense at day 4 and gradually decreased during the middle stages of pregnancy, only to increase again towards the end of pregnancy. Casey ef al. (1992) reported that PTHrP is secreted from endometrial stromal cells grown in monolayer culture. PTHrP produced by these cells could be involved in control of endometrial proliferation and differentiation, as the induction of differentiation has been associated with changes in PTHrP production in keratinocytes (Henderson et al., 1991; Löwik et al., 1992). PTHrP mRNA is detected in the epithelium of the anti-mesometrial crypts of the uterus, marking the sites of implantation (Beck et al., 1993). The expression of PTHrP mRNA in the uterine epithelium is followed by the detection of PTHrP mRNA $48 \mathrm{~h}$ later in the developing embryo, and PTHrP mRNA can be detected in early post-implantation trophoblastic giant cells (Senior et al., 1991). The striking correlation between the distribution and period of expression of PTHrP protein and mRNA in embryonic and uterine tissues suggests that PTHrP has a role in implantation. Moreover, at this time the myometrium is responsive to the relaxing action of PTHrP and taken with the overall evidence suggests that PTHrP may be involved in implantation, either directly or by inhibiting the expulsion of free blastocysts.

Changes in PTHrP mRNA have been reported in human amnion, which had the highest abundance of mRNA of all uteroplacental tissues examined (Ferguson et al., 1992). After the onset of labour, PTHrP mRNA decreased in the amnion, but not in other tissues. As PTHrP (1-34) had no effect on uterine contractility during the last third of pregnancy in the study reported here, it is likely that PTHrP has more than one 
role in the maintenance of pregnancy. For example, in utero, the tissues of the conceptus could be affected by PTHrP derived either from the endometrium or the amnion, as van de Stolpe et al. (1993) demonstrated that embryonic stem cells (ES-5) and embryonal carcinoma cells (F9) that have been induced to differentiate towards a parietal endoderm-like phenotype have $\mathrm{PTH}$ or $\mathrm{PTHrP}$ receptor mRNA. In addition, PTHrP can upregulate the expression of its own receptor mRNA in these cell lines (van de Stolpe et al., 1993).

In conclusion, $\mathrm{PTHrP}$ has been shown to relax the rat uterus at early stages of pregnancy in vitro. However, the tissue becomes less sensitive to $\mathrm{PTHrP}$ as pregnancy progresses, suggesting that PTHrP produced in the uterus is unlikely to have a role in parturition as first proposed (Thiede et al., 1990). The temporal pattern of PTHrP production in the uterus of the pregnant rat is striking, and such modulation in PTHrP concentration throughout pregnancy strongly suggests that this hormone has an important physiological role during pregnancy.

The authors would like to thank M. Brooks and the staff in Animal House (Department of Pharmacology, University of Melbourne) for their invaluable assistance with the mating programme. This work was supported by grants from the National Health and Medical Research Council of Australia and the Dairy Research and Development Corporation of Australia.

\section{References}

Abbas SK, Pickard DW, Rodda CP, Heath JA, Hammonds RG, Wood WI, Caple IW, Martin TJ and Care AD (1989) Stimulation of ovine placental calcium transport by purified natural and recombinant parathyroid hormone-related protein (PTHrP) preparations Quarterly Journal of Experimental Physiology 74 $549-552$

Barri MES, Abbas SK and Care AD (1992) The effects in the rat of two fragments of parathyroid hormone-related protein on uterine contractions in situ Experimental Physiology 77 481-490

Beck F, Tucci J and Senior PV (1993) Expression of parathyroid hormone-related protein mRNA by uterine tissues and extraembryonic membranes during gestation in rats Joumal of Reproduction and Fertility $99343-352$

Bengtsson B, Chow EMH and Marshall JM (1984) Activity of circular muscle of rat uterus at different times in pregnancy American Journal of Physiology 246 C216-C223

Casey ML, Mibe M, Erk A and MacDonald PC (1992) Transforming growth factor- $\beta_{1}$ stimulation of parathyroid hormone-related protein expression in human uterine cells in culture: mRNA levels and protein secretion Journal of Clinical Endocrinology and Metabolism 74 950-952

Chamley WA and Parkington HC (1984) Relaxin inhibits the plateau component of the action potential in the circular myometrium of the rat journal of Physiology 353 51-65

Danks JA, Ebeling PR, Hayman JA, Chou ST, Moseley JM, Dunlop J, Kemp BE and Martin TJ (1989) Parathyroid hormone-related protein: immunohistochemical localization in cancers and normal skin Joumal of Bone and Mineral Research 4 273-278

Danks JA, Ebeling PR, Hayman JA, Diefenbach-Jagger H, Collier FMCL, Grill V, Southby J, Moseley JM, Chou H and Martin TJ (1990) Immunohistochemical localization of parathyroid hormone-related protein in parathyroid adenoma and hyperplasia Journal of Pathology 161 27-33

Ferguson JE, Gorman JV, Bruns DE, Weir EC, Burtis WJ, Martin TJ and Bruns ME (1992) Abundant expression of parathyroid hormone-related protein in human amnion and its association with labour Proceedings National Academy of Sciences USA $\mathbf{8 9} 8384-8388$
Hashimoto I, Hendricks DM, Anderson LL and Melampy RM (1968) Progesterone and pregn-4-en-20 $\alpha$-ol-3-one in ovarian venous blood during various reproductive states in the rat Endocrinology $\mathbf{8 2} 333-341$

Hellman P, Ridefelt P, Juhlin C, Åkerström G, Rastad J and Gylfe E (1992) Parathyroid-like regulation of parathyroid-hormone-related protein release and cytoplasmic calcium in cytotrophoblast cells of human placenta Archives of Biochemistry and Biophysics 293 174-180

Henderson J, Sebag M, Rhim J, Goltzman D and Kremer R (1991) Dysregulation of parathyroid hormone-like peptide expression and secretion in a keratinocyte model of tumor progression Cancer Research 51 6521-6528

Kemp BE, Moseley JM, Rodda CP, Ebeling PR, Wettenhall RE, Stapleton D, Diefenbach-Jagger $H$, Ure F, Michelangeli VP, Simuons HA, Raitz LG and Martin TJ (1987) Parathyroid hormone-related protein of malignancy: active synthetic fragments Science 238 1568-1570

Löwik CWGM, Hockman K, Offringa R, Groot CG, Hendy GN, Papapoulos SE and Ponec M (1992) Regulation of parathyroid hormone-like protein production in cultured normal and malignant keratinocytes Joumal of Investigative Dermatology 98 198-203

MacIsaac RJ, Caple IW, Danks JA, Diefenbach-Jagger H, Grill V, Moseley JM, Southby J and Martin TJ (1991) Ontogeny of parathyroid hormone-related protein in the ovine parathyroid gland Endocrinology 129 757-764

Paspaliaris V, Vargas SJ, Gillespie MT, Williams ED, Danks JA, Moseley JM, Story ME, Pennefather IN, Leaver DD and Martin TJ (1992) Oestrogen enhancement of the myometrial response to exogenous parathyroid hormone-related protein (PTHrP), and tissue localisation of endogenous PTHrP and its mRNA in the virgin rat uterus Joumal of Endocrinology 134 $415-425$

Rakopoulos M, Leaver DD, Ho PMW, Vargus SJ, Moseley JM and Martin TJ (1992) Production of parathyroid hormone-related protein by the mammary gland in pregnancy and lactation American Journal of Physiology 263 E1077-E1085

Senior PV, Heath DA and Beck F (1991) Expression of parathyroid hormonerelated protein mRNA in the rat before birth: demonstration by hybridization histochemistry Journal of Molecular Endocrinology 6 281-290

Shaik AA (1971) Estrone and estradiol levels in the ovarian venous blood from rats during the estrous cycle and pregnancy Biology of Reproduction 5 297-307

Southby J, Kissiin MW, Darks JA, Hayman JA, Moseley JM, Henderson MA, Bennett RC and Martin TJ (1990) Immunohistochemical localization of parathyroid hormone-related protein in human breast cancer Cancer Research $607710-7716$

Thiede MA and Rodan GA (1988) Expression of a calcium-mobilizing parathyroid hormone-like peptide in lactating mammary tissue Science $\mathbf{2 4 2}$ $278-280$

Thiede MA, Daifotis AG, Weir EC, Brines ML, Burtis WJ, Ikeda K, Dreyer BE, Garfield RE and Broadus AE (1990) Intrauterine occupancy controls expression of the parathyroid hormone-related peptide gene in preterm rat myometrium Proceedings of the National Academy of Sciences, USA 87 6969-6973

Thiede MA, Harm SC, Hasson DM and Gardner RM (1991) In vivo regulation of parathyroid hormone-related peptide messenger ribonucleic acid in the rat uterus by 17 $\beta$-estradiol Endocrinology 128 2317-2323

Trizna W and Edwards RM (1991) Relaxation of renal arterioles by parathyroid hormone and parathyroid hormone-related protein Pharmacology $\mathbf{4 2}$ 91-96

van de Stolpe A, Karperien M, Löwik CWGM, Jüppner H, Segre GV, Abou-Samra A-A, de Laat SW and Defize LHK (1993) Parathyroid hormonerelated peptide as an endogenous inducer of parietal endoderm differentiation Journal of Cell Biology 120 235-243

Walters CA, Daly DC, Chapitis J, Kuslis ST, Prior JC, Kusmik WF and Riddick DH (1983) Human myometrium: a new potential source of prolactin American Journal of Obstetrics and Gynecology $147639-640$

Winquist RJ, Baskin EP and Vlasuk GP (1987) Synthetic tumor-derived human hypercalcemic factor exhibits parathyroid hormone-like vasorelaxation in renal arteries Biochemical and Biophysical Research Communications 149 227-232 